\title{
Edukacja rachunkowości w czasach pandemii - wirtualny wymiar dydaktyki i wnioski na przyszłość
}

\author{
Accounting Education in times of the COVID-19 pandemic - \\ virtual teaching and implications for the future
}

\begin{abstract}
Streszczenie
Pandemia COVID-19 znacząco przyspieszyła transformację kształcenia z modelu tradycyjnego do wirtualnego. Celem artykułu jest prezentacja najistotniejszych wyzwań dydaktycznych, przed którymi stanęli wykładowcy rachunkowości w okresie pandemii. Na ich podstawie przeanalizowany został problem metodyki nauczania oraz zakresu merytorycznego w kształceniu rachunkowości w przyszłości. Realizacja celu wymagała zastosowania takich metod badawczych, jak analiza materiałów źródłowych oraz metody indukcji i dedukcji. Pierwsze doświadczenia pandemiczne w kształceniu rachunkowości to intensywna praca nad przemyśleniem i przeprojektowaniem wykorzystywanego w wielu przypadkach wyłącznie tradycyjnego kształcenia przy tablicy na wykorzystanie e-learningu. Przebudowanie i aktualizacja materiałów dydaktycznych w połączeniu z technicznymi problemami była bardzo czasochłonna. W edukacji rachunkowości zaczęto wykorzystywać nowe metody, takie jak: flipped learning, microlearning, crowdlearning. Poza omówieniem nowoczesnych metod kształcenia w artykule zwrócono uwagę na konieczność uzupełnienia lub poszerzenia zakresu merytorycznego o zagadnienia związane z prowadzeniem usług księgowych
\end{abstract}

1 Justyna Kłobukowska, Wydział Nauk Ekonomicznych i Zarządzania, Uniwersytet Mikołaja Kopernika w Toruniu, Polska, e-mail: j.klobukowska@prokonto.pl, ORCID ID: https://orcid. org/0000-0002-4963-4237. 
online oraz cyberbezpieczeństwa w biurach rachunkowości. Dodatkowym wyzwaniem jest zapewnienie odpowiedniego poziomu kształcenia w dobie rosnących wyzwań związanych z raportowaniem zrównoważonego rozwoju przez podmioty gospodarcze.

\title{
Słowa kluczowe:
}

rachunkowość, edukacja, nauczanie zdalne, e-księgowość, zintegrowane raportowanie, informacje niefinansowe

\begin{abstract}
The COVID-19 pandemic has significantly accelerated the transformation of education from a traditional to a virtual model. The aim of this study is to present the most important didactic challenges faced by accounting lecturers during the pandemic. On their basis, the problem of teaching methods and the substantive scope in accounting education in the future was analyzed. The basic research methods used are literature studies, as well as formulating conclusions on the basis of the deduction and synthesis methods. The first pandemic experiences in accounting education were intensive work on rethinking and redesigning the in many cases exclusively traditional blackboard education for the use of e-learning. The rebuilding and updating of teaching materials, combined with technical problems, was very time consuming. In accounting education, new methods such as flipped learning, microlearning, crowdlearning have been introduced. In addition to discussing modern methods of education, the article highlights the need to supplement or extend the substantive scope with issues related to online accounting services and cybersecurity in accounting offices. An additional challenge is to ensure an adequate level of education in the times of growing challenges related to reporting sustainable development by economic entities.
\end{abstract}

\section{Keywords:}

accounting, education, online learning, e-accounting, integrated reporting, non-financial information

\section{WSTĘP}

Zmiany globalne wynikające ze wzrostu poziomu cyfryzacji społeczeństwa, a także świadomości ekologicznej, powiązane z przemianami pokoleniowymi, przyczyniają się do istotnych przeobrażeń społeczno-gospodarczych. Dynamika tych zmian istotnie została przyspieszona kryzysem zdrowotnym na świecie związanym 
z rozpowszechnianiem się zachorowań na COVID-19.

W obliczu koniecznego dystansu fizycznego narzędzia teleinformatyczne służące porozumiewaniu i przekazywaniu informacji na odległość kreują wizję pracy i edukacji na kolejne dziesięciolecia XXI wieku. Kształcenie w czasach pandemii wiązało się z koniecznością dostosowania sposobu przekazania wiedzy do nowych warunków oraz wypracowania rozwiązań metodycznych służących jak najefektywniejszemu rozwojowi studentów.

Ciągłe doskonalenie, uzależnienie od uwarunkowań wewnętrznych i zewnętrznych, opracowanie i dostarczanie informacji należą do jednych z zadań rachunkowości. Studenci podczas kształcenia przekonują się, że stanowi ona ważny element systemu informacyjnego przedsiębiorstwa. Poznają jego strukturę, metody i zasady funkcjonowania oraz kategorie ekonomiczno-finansowe (Gmińska, 2018, s. 238-239).

Celem artykułu jest prezentacja najistotniejszych wyzwań dydaktycznych, przed którymi stanęli wykładowcy rachunkowości w okresie pandemii. Na ich podstawie przeanalizowany został problem metodyki nauczania oraz zakresu merytorycznego w kształceniu rachunkowości w przyszłości.

Realizacja postawionego celu wymagała zastosowania adekwatnych metod badawczych, takich jak analiza materiałów źródłowych oraz metody indukcji i dedukcji. Dokonano analizy wyników badań wtórnych na temat międzynarodowych doświadczeń w zakresie edukacji rachunkowości w okresie. Przeprowadzono desk research w zakresie analizy trendów, projektowanych regulacji prawnych w obszarze rachunkowości, które implikować będą na przygotowanie zawodowe w przyszłości. Wnioski sformułowane w niniejszym artykule wynikają również z własnych obserwacji i doświadczeń dydaktycznych autorki zdobytych podczas prowadzenia zajęć dydaktycznych.

\section{WIRTUALNA DYDAKTYKA RACHUNKOWOŚCI W PANDEMII - GŁÓWNE WYZWANIA}

\subsection{WYZWANIA EDUKACJI RACHUNKOWOŚCI W OPINII WYKŁADOWCÓW}

Do momentu ścisłego wprowadzenia obostrzeń związanych z pandemią COVID-19 e-learning był jedną z form nauczania na odległość. Nauczanie w środowisku wirtualnym za pośrednictwem nowoczesnych technologii informacyjnych wspierało proces przekazywania lub utrwalania wiedzy. Stanowiło również czynnik wyróżniający ofertę studiów pomiędzy uczelniami, umożliwiając poszerzanie wiedzy 
w dowolnym czasie słuchaczom łączącym obowiązki zawodowe czy rodzinne. Przywołując wyniki badań z 2014 r., większość ankietowanych instytucji posiadała w ofercie e-learning, a ponad połowa oferowała lub planowała otworzyć kierunki oparte na programach studiów online (Gaebel, Kupriyanova, Morais i Colucci, 2013).

Ogłoszenie w marcu 2020 r. obostrzeń związanych z negatywnymi statystykami zachorowań niezależnie od tego, czy w programie kształcenia przewidywano kształcenie online, spowodowało, że nauczyciele akademiccy rozpoczęli zdalne nauczanie. Szczególnie w pierwszym okresie głównym narzędziem była poczta elektroniczna, zarówno w procesie komunikacji, jak i przesyłania materiałów dydaktycznych (Sangster, Stoner i Flood, 2020, s. 518). Podobnie jak na innych kierunkach, w procesie kształcenia rachunkowości zajęcia prowadzono głównie przy użyciu takich platform, jak: Moodle, Umail w systemie USOSweb, programów MS Teams, Zoom.us, ClickMeeting, Google Classroom lub BigBlue Button.

Jednocześnie testowano i szukano rozwiązań, które pozwolą na jak największą interakcję między studentami a wykładowcami. Bardzo istotny był wybór narzędzi umożliwiających jak największą dostępność materiałów dydaktycznych, przy uwzględnieniu różnego stopnia umiejętności posługiwania się nowymi aplikacjami, wyposażenia w sprzęt komputerowy i dostępu do sieci internetowej.

W 2020 r. przeprowadzono badanie wśród 66 nauczycieli akademickich z 45 krajów na temat wpływu pandemii COVID-19 na edukację rachunkowości. Wykładowcy z poszczególnych krajów podzielili się swoimi odczuciami na temat wyzwań wynikających z kształcenia w czasie kryzysu (sukcesy, porażki) oraz zwrócili uwagę na potencjalne problemy badawcze dotyczące edukacji rachunkowości wynikające z kryzysu (Sangster, Stoner i Flood, 2020). Wśród wypowiedzi przeważały odczucia negatywne, związane z pracochłonnością i czasochłonnością dokonywania zmiany sposobu przygotowania się do przeprowadzenia zajęć i systemu oceniania, co przedstawia tabela 1. Należy podkreślić, że zarówno wśród dydaktyków, jak i studentów wzrósł poziomu stresu związanego z kształceniem zdalnym.

Tabela 1. Wypowiedzi wykładowców rachunkowości na temat kształcenia online w pandemii

\begin{tabular}{llcc}
\hline Lp. & \multicolumn{1}{c}{ Wyszczególnienie } & L. odp. & \% \\
\hline 1 & $\begin{array}{l}\text { System oceniania został zmieniony, aby dopasować do warunków } \\
\text { kształcenia online }\end{array}$ & 24 & 53,3 \\
\hline 2 & Stres - wykładowcy & 22 & 48,9 \\
\hline 3 & Znacząco wzrosło obciążenie pracą & 20 & 44,4 \\
\hline
\end{tabular}




\begin{tabular}{llrcr}
\hline Lp. & \multicolumn{1}{c}{ Wyszczególnienie } & L. odp. & \% \\
\hline 4 & $\begin{array}{l}\text { Blended learning, uwzględniające interakcje „twarzą w twarz”, będzie } \\
\text { nowym „normalnym” sposobem nauczania }\end{array}$ & 18 & 40 \\
\hline 5 & Stres - uczniowie & 17 & 37,8 \\
\hline 6 & Problemy z dostępem do Internetu & 15 & 33,3 \\
\hline 7 & Mniej zaangażowani studenci & 15 & 33,3 \\
\hline 8 & Nadzorowanie przebiegu zajęć & 11 & 24,4 \\
\hline 9 & Wydział musiał szybko uczyć się nowych umiejętności & 10 & 22,2 \\
\hline 10 & Studenci niewyposażeni w komputery, tablety lub smartfony & 8 & 17,8 \\
\hline 11 & Studenci nie włączają swoich kamer podczas zajęć & 7 & 15,6 \\
\hline 12 & Problemy z przeciążeniem łączy szerokopasmowych & 6 & 13,3 \\
\hline 13 & Zmiany systemu oceniania ograniczone / opóźnione przez akredytację & 6 & 13,3 \\
\hline 14 & Studenci oczekują spotkań twarzą w twarz & 6 & 13,3 \\
\hline 15 & Wykładowca odczuwa izolację (brak mowy ciała studenta / informacji & 5 & 11,1 \\
& zwrotnej na zajęciach synchronicznych) & 5 & 11,1 \\
\hline 16 & Studenci podczas zajęć online są mało aktywni & 4 & 8,9 \\
\hline 17 & Biurokracja & 4 & 8,9 \\
\hline 18 & Utracone strumienie przychodów (wynikające z tego ryzyko) & 4 & 8,9 \\
\hline 19 & Studentom podobała się elastyczność zajęć przez Internet & 4 & 8,9 \\
\hline 20 & Studenci wyłączali mikrofon & 5
\end{tabular}

Źródło: (Sangster, Stoner i Flood, 2020, s. 438).

Dwie kwestie określono jako pozytywne (tabela 1, poz. 4 i 19). Wielu studentów pozytywnie ocenia studiowanie przez Internet ze względu na elastyczność tej formy. Przeniesienie edukacji na platformy wirtualne przyniosło pewne korzyści, np. w postaci braku konieczności dojazdu do uczelni. Podkreślono, że blended learning może stanowić przyszły sposób edukacji. Platformy e-learningu nie zastąpią tradycyjnego systemu edukacji, ale mogą istotnie wpłynąć na wzrost jakości kształcenia.

\subsection{METODY DYDAKTYCZNE I MOTYWOWANIE DO AKTYWNOŚCI PODCZAS E-ZAJĘĆ Z RACHUNKOWOŚCI}

Pierwsze doświadczenia pandemiczne w kształceniu rachunkowości to intensywna praca nad przemyśleniem i przeprojektowaniem wykorzystywanego w wielu przypadkach wyłącznie tradycyjnego kształcenia przy tablicy na wykorzystanie e-learningu. Przebudowanie i aktualizacja materiałów dydaktycznych w połączeniu z technicznymi problemami pochłaniała mnóstwo energii i w bardzo krótkich 
odstępach czasu musiała być dostarczona studentom.

Uczelnie były bardzo skupione na wspieraniu studentów, zarówno merytorycznym, psychologicznym, jak i technicznym. Nie zawsze studenci mogli wziąć udział w zajęciach synchronicznych ze względu na sytuację rodzinną i lokalową. Pomaganie studentom odbywało się w różnych formach. W zakresie technicznym uczelnie pośredniczyły w dostarczeniu komputerów, korzystnej oferty lub darmowego dostępu do Internetu, a także planowały sposób prowadzenia zajęć i rodzaj wykorzystywanych narzędzi w odniesieniu do ewentualnych przeciążeń szerokopasmowych łączy internetowych.

W przypadku zajęć synchronicznych online studenci doceniali nagrania wykładów, dzięki czemu możliwe było ich wysłuchanie w całości, w przypadku gdy mieli oni trudności techniczne z połączeniem internetowym. Zapewniano dodatkowy czas podczas egzaminów prowadzonych online dla studentów z większymi potrzebami. Wykładowcy podejmowali wiele działań pomagających zauważyć studentom korzyści zdobywania wiedzy w warunkach e-learningu. Włączano do programu zajęć materiały zewnętrzne zapewniające zwiększenie różnorodności i wzmagające zainteresowanie (Sangster, Stoner i Flood, 2020, s. 442). Należy przypomnieć, że w przeprowadzonych przez Klinowskiego (2017) badaniach na temat metod nauczania rachunkowości podatkowej w roku akademickim 2016/2017 studenci oczekiwali od wykładowców korzystania z multimedialnych technik wizualizacji. Poszukiwania najatrakcyjniejszych sposobów przekazywania wiedzy z zakresu rachunkowości przed pandemią prowadziło już wielu badaczy (Gmińska, 2018), (Drumlak, 2011).

Należy jednak podkreślić, że wielu edukatorów rachunkowości stanęło przed decyzją sposobu prowadzenia zajęć pomiędzy ich realizacją w czasie rzeczywistym a asynchronicznym. Rozważając argumenty za i przeciw dotyczące obu tych sposobów, ich doświadczenia w prowadzeniu zajęć w okresie pandemii doprowadziły do innej konstatacji, a mianowicie, że przy podejmowaniu decyzji najistotniejsze jest jak najlepiej motywować studentów do aktywności podczas zajęć (Sangster, Stoner i Flood, 2020, s. 449). Przy takim założeniu oraz zrozumieniu specyfiki nadzwyczajnych warunków, w jakich prowadzone jest nauczanie, wielu wykładowców przyznało, że zajęcia synchroniczne online nie są najlepszym rozwiązaniem. Tym samym zakwestionowano tradycyjny model nauczania. Stąd też coraz częściej bardzo pozytywnie odbiera się odwróconą klasę (flipped learning). Wyróżnia się ono tym, że zapoznawanie się z materiałem odbywa się online lub offline, przed zajęciami synchronicznymi. Zajęcia na żywo mogą zostać wykorzystane na dyskusję nad materiałami, doprecyzowanie czy wyjaśnienie niezrozumiałych kwestii (Alhawsawi, 2019, s. 80). 
Kolejnym rozwiązaniem wpływającym na zwiększenie koncentracji podczas nauki zdalnej w rachunkowości jest microlearning, rozumiany jako mniejsze bloki tematyczne (Arnab, Walaszczyk, Lewis i Kernaghan-Andrews, 2021). Wydzielanie określonego fragmentu sprawdza się zarówno we wzmacnianiu wiedzy, jak i w efektywnym powtarzaniu materiału.

Innym interesującym przykładem jest crowdlearning, który możemy rozumieć jako uczenie się w tłumie lub od tłumu (Baszyński, 2020, s. 52-53). Odnosi się do metodyki uczenia przez działanie (ang. learning-by-doing), co ma istotny wpływ na wykorzystanie praktycznego charakteru takiej formy w kształceniu rachunkowości. Wykorzystanie cech zbiorowej inteligencji, wśród których należy wymienić wspólną pracę, cele, podejmowanie decyzji, udzielanie wsparcia i rozwiązywanie problemów, pozwala na kształtowanie zarówno kompetencji miękkich, jak i twardych (Baszyński, 2020, s. 53). W połączeniu z metodami projektowymi, pracą w interdyscyplinarnych grupach osiągnięcie praktycznych umiejętności księgowania operacji gospodarczych czy analizy sprawozdań finansowych może istotnie pozytywnie oddziaływać na efekty kształcenia.

Wymiana doświadczeń z uwzględnieniem regionalnych i instytucjonalnych czynników, które miały wpływ na proces nauczania w różnych krajach, generuje wiedzę i kierunki do dalszych badań nad przyszłością edukacji rachunkowości (Sangster, Stoner i Flood, 2020, s. 444-445). Wykładowcy rachunkowości powinni wykorzystać doświadczenia zdobyte w kryzysie i jednocześnie przełożyć je na przyszłe wyzwania, zarówno w środowisku kształcenia teoretycznego, jak i praktycznego. Przedstawione sugestie nie wyczerpują możliwości rozszerzenia na inne kategorie i elementy analizy przyszłych kierunków edukacji rachunkowości.

\section{ZAKRES MERYTORYCZNY W EDUKACJI RACHUNKOWOŚCI W ERZE POST-COVID}

\subsection{OD RACHUNKOWOŚCI TRADYCYJNEJ DO USŁUG KSIĘGOWYCH ONLINE}

Rozprzestrzenianie się pandemii COVID-19, a w dalszej kolejności wprowadzane odgórnie obostrzenia wymagały od różnych organizacji, w tym szczególnie przedsiębiorstw, podejmowania strategicznych zmian. W przypadku kształcenia przyszłych ekonomistów istotna jest dyskusja, jakie kompetencje i w jaki sposób wzmacniać w procesie kształcenia, aby w przypadkach dynamicznych zmian stanowili wsparcie dla biznesów, w których są zatrudnieni lub dla których będą usługodawcami. W przypadku studentów, którzy wybierają zawód księgowego, 
istotne jest poruszenie kwestii wyzwań, w obliczu których stanęły biura rachunkowe podczas pandemii.

W odniesieniu do działalności biur rachunkowości mogliśmy zaobserwować zmiany w przepisach i wzrost obowiązków związanych z obsługą tarcz antykryzysowych. Na działalność biur rachunkowych miały wpływ również zawieszenie lub zamykania działalności przez podmioty, w stosunku do których były świadczone usługi księgowe (Biura rachunkowe, 2020). Wzrosła potrzeba obsługiwania klientów przez Internet, bo dostarczanie dokumentów drogą papierową było wręcz niemożliwe. Istotna okazała się umiejętność komunikacji i organizacji spotkań online z dotychczasowymi klientami oraz poszukiwaniem nowych, którzy w okresie pandemii wchodzili na rynek z nowymi usługami. Należy spodziewać się, że wśród tych przedsiębiorstw będą nowe biura rachunkowe lub banki, które coraz częściej oferują bankowe usługi księgowe online. Mogą okazać się konkurentami dla istniejących firm z branży księgowej, co powinno motywować do pogłębionych działań w zakresie badania potrzeb klientów i profesjonalizacji usług (Biura rachunkowe, 2020).

Dynamiczny rozwój technologii teleinformatycznych w rachunkowości powoduje, że obecne systemy informatyczne rachunkowości wykraczają poza tradycyjne, których funkcje ograniczały się do prowadzenia księgi głównej, obsługi sprzedaży czy magazynu (Król-Stępień, 2013). W skutecznym zarządzaniu przedsiębiorstwem wykorzystywane są systemy finansowo-księgowe, inaczej ERP (ang. enterprises resource planning). Oprogramowania tego typu pozwalają odpowiadać kompleksowo na pytania na temat sytuacji wewnątrz przedsiębiorstwa, dzięki wymianie i archiwizowaniu dokumentów w wersji elektronicznej. Co istotne, przechowywanie dokumentacji księgowej w wersji elektronicznej jest zgodne z Ustawą o rachunkowości i akceptowalne w komunikacji z urzędami skarbowymi (Soczewka-Piwowarczyk, 2020). Jak pokazują badania, niemal 90\% badanych Polaków oczekuje, że będzie mogło przechowywać całą swoją korespondencję elektronicznie, również faktury. Zamiast przesyłać wrażliwe dane drogą mailową, księgowi dzięki nowoczesnym rozwiązaniom IT mogą kontaktować się z klientem za pomocą specjalnych programów (INFOR 2020).

Wszelkie działania prowadzone w zakresie e-księgowości czy e-biura rachunkowego powinny być bezpieczne. Stąd też zapewnienie bezpieczeństwa wirtualnych danych staje się priorytetem dla każdego przedsiębiorcy (Soczewka-Piwowarczyk, 2020). Cyberbezpieczeństwo jest kluczowym elementem świadczenia profesjonalnych usług w branży księgowej. Widząc takie potrzeby, istotne jest przeanalizowanie możliwości zwiększenia liczby godzin dydaktycznych rachunkowości 
komputerowej, a także dotyczących organizacji pracy zdalnej biur czy działów księgowych oraz cyberbezpieczeństwa.

Coraz częściej mowa o zagrożeniach dla przyszłej pracy księgowych w związku z automatyzacją i robotyzacją wielu czynności. Tym bardziej w kształceniu przyszłych księgowych należy kłaść nacisk na interpretację danych, wnioskowanie i logiczne myślenie. Istotne jest również posiadanie aktualnej wiedzy na temat regulacji prawnych, w tym podatkowych. W gąszczu zmian maszyna zaprogramowana na księgowanie podstawowych operacji gospodarczych czy sczytywanie danych z dokumentów nie jest w stanie zastąpić księgowego. Pozytywnym aspektem robotyzacji czynności jest uwolnienie czasu pracowników biur rachunkowych, dzięki czemu mają oni czas na bardziej dogłębną analizę potrzeb klientów, dokonywanie specjalistycznych interpretacji i samorozwój (INFOR, 2020).

\subsection{OD RACHUNKOWOŚCI FINANSOWEJ DO RAPORTOWANIA DANYCH POZAFINANSOWYCH}

Wzrost znaczenia pozaekonomicznych czynników w zarządzaniu organizacjami w kierunku społecznej odpowiedzialności biznesu wpłynął na ewolucję finansów i rachunkowości finansowej. Rozszerzone zostały obowiązki sprawozdawcze. W zakresie regulacji prawnych przełomowym etapem było wdrożenie unijnej Dyrektywy 2014/95/UE. Dokonano zmiany w zapisach Ustawy o rachunkowości, w której wprowadzono wymogi rozszerzonego raportowania informacji niefinansowych. Z kolei w rozporządzeniu w sprawie informacji bieżących i okresowych zaktualizowane zostały wytyczne dotyczące wymogów ujawniania informacji o polityce różnorodności w obszarze organów przedsiębiorstw (Kłobukowska, 2020).

Największe spółki giełdowe były zobligowane do poszerzonego raportowania niefinansowego od ponad trzech lat. Mimo posiadanych na tym polu doświadczeń, według analiz przeprowadzonych przez Fundację Standardów Raportowania oraz SEG, wśród 151 spółek giełdowych, które zaraportowały dane niefinansowe za 2019 r., niemal 60\% z nich nie sporządziło raportów zgodnie z uznanymi standardami raportowania (Błaszczak, 2021). Trwają prace nad doprecyzowaniem i rozszerzeniem regulacji. Znowelizowana dyrektywa 2014/95/UE będzie dotyczyła raportów na temat trzech istotnych zagadnień zrównoważonego rozwoju, w skrócie ESG+. Obszar „E” dotyczyć będzie kapitału naturalnego, obszar „S” kapitału ludzkiego, relacyjnego i społecznego, a obszar G+ kapitału intelektualnego (Biernacki, 2021). Prace Komisji Europejskiej były nakierowane na ujednolicenie formy sprawozdań, co umożliwi zwiększenie ich przejrzystości i porównywalności 
danych. Ogłoszenie projektu rewizji dyrektywy planowane jest w drugim kwartale $2021 \mathrm{r}$.

Należy podkreślić, że raportowanie tak szerokich danych wiąże się z interdyscyplinarnym procesem polegającym na zbieraniu, przetwarzaniu, a następnie wieloaspektowej prezentacji danych o działalności organizacji (Chłapek, Krajewska i Jonas, 2019, s. 24). Co istotne, tematyka raportowania danych pozafinansowych generalnie nie funkcjonuje jako odrębny przedmiot, częściej stanowi jeden z modułów omawianych w ramach innych wykładanych przedmiotów. Należy również podkreślić, że zagadnienia poruszane są najczęściej na studiach drugiego stopnia lub podyplomowych.

Wyniki badania przeprowadzonego przez Chłapek, Krajewską i Jonas (2019) wśród nauczycieli akademickich prowadzących zajęcia z przedmiotów związanych z rachunkowością dotyczące problematyki raportowania zintegrowanego potwierdziły hipotezę badaczy o „konieczności zrównoważenia paradygmatu nauczania i uczenia się w aspekcie dalszego rozwoju koncepcji sprawozdawczości zintegrowanej, a nie dokonywanie radykalnego wyboru pomiędzy tradycyjnym a nowoczesnym modelem nauczania (Chłapek, Krajewska i Jonas, 2019, s. 24).

Przygotowanie studentów pod kątem umiejętności raportowania danych pozafinansowych powinno stanowić jedno z kluczowych kierunków rozwoju programów zajęć na uczelniach wyższych. Na rynku pracy będą poszukiwani specjaliści z zakresu łączenia informacji finansowych i niefinansowych prezentowanych w sprawozdaniach na temat zrównoważonego rozwoju organizacji. Absolwenci wyposażeni w odpowiednie kompetencje szybciej znajdą zatrudnienie.

\section{PODSUMOWANIE}

Międzynarodowe doświadczenia związane z kształceniem rachunkowości w okresie pandemii pokazują duży progres w zakresie cyfryzacji oraz wykorzystania nowoczesnych technologii w nauczaniu. Konieczność zmiany modelu kształcenia była gwałtowna, przez co okazało się czynnikiem wysoce stresogennym zarówno dla wykładowców, jak i uczniów. Bariery techniczne, wskazywane jako jedne z głównych przeszkód w realizacji zdalnego kształcenia, będą w dłuższym okresie niwelowane. Na bazie doświadczeń należy spodziewać się wykorzystywania pozytywnych stron zdalnej nauki do zwiększania jej efektywności.

Prowadzenie kursów rachunkowości zdalnie w okresie pandemii pokazało, że wiele aspektów związanych z księgowaniem operacji gospodarczych, a także aspektów prawnych ujętych w programach kształcenia, może być efektywnie 
przekazywanych w ramach e-zajęć. Kształcenie online jest dostępną, elastyczną i bezpieczną formą edukowania. Wspiera rozwój studenta rachunkowości w zakresie samodyscypliny, organizacji czasu, kreatywności, co umożliwia rozwój jego kompetencji miękkich. Programy e-learningowe odciążają czas wykładowcy. Z przekazywania podstaw teoretycznych może on zostać przekierowany na wykorzystanie jednostek dydaktycznych podczas zajęć synchronicznych na dyskusję nad zagadnieniami, wyjaśnianie trudniejszych kwestii. Takie działania przybliżają do modelu odwróconej szkoły.

Edukacja rachunkowości po pandemii jest kształtowana przez wizję zawodu ekonomisty, księgowego czy audytora. Środowisko pracy i wymagane kompetencje dla przyszłych adeptów rachunkowości zmieniały się historycznie. Należy monitorować zarówno potrzeby studentów, jak i ich potencjalnych pracodawców wobec oferowanych przedmiotów w programie kształcenia. W pierwszej kolejności istotne będzie zwiększenie liczby godzin dydaktycznych z zakresu zastosowania systemów informatycznych oraz rozszerzenie zakresu merytorycznego o aspekty zrównoważonego rozwoju w rachunkowości. Należy spodziewać się, że zdobyte doświadczenia w okresie pandemii zainspirują do zaprojektowania, wdrożenia nowych kursów lub modułów w programach kształcenia.

O przewadze konkurencyjnej uczelni świadczyć będzie przygotowanie studentów do pracy w ujęciu hybrydowym. Istotne jest, aby w postpandemicznym systemie edukacji rachunkowości do zawodu przygotowywać w oparciu o metody tradycyjne, ale z uwzględnieniem doświadczeń ze zdalnej nauki. Analizując zmieniające się otoczenie społeczno-gospodarcze, wyzwania ekologiczne i technologiczne, należy skonstatować, że zarówno metody kształcenia, jak i zakres merytoryczny powinien odpowiadać na przyszłe potrzeby biznesu, a szerzej postpandemicznej gospodarki.

\section{Bibliografia}

Alhawsawi, M. (2019). Preparing Accounting Students for the Labor Market after COVID-19, Opportunities, and Challenges. Australian Academy of Accounting and Finance Review, 5, 2, s. 77-84.

Arnab, S., Walaszczyk, L., Lewis, M., Kernaghan-Andrews, S. (2021). Designing Mini-Games as Micro-Learning Resources for Professional Development in Multi-Cultural Organisations. The Electronic Journal of e-Learning, 19, 2, s. 44-58. DOI: 10.34190/ ejel.19.2.2141.

Baszyński, A. (2020). Crowdlearning - nauka poprzez interakcję z innymi. Przegląd ekonomiczny, 20, s. 52-59. 
Biernacki, P. (26.03.2021). Wielka zmiana w raportowaniu. Rzeczpospolita, Dodatek specjalny Biznes Odpowiedzialny w Polsce, s. S9.

Biura rachunkowe (2020). Rozwój biura rachunkowego w czasie pandemii. Pobrano z: https:/www.biura-rachunkowe.waw.pl/artykul/rozwoj-biura-rachunkowego-w-czasie-pandemii-159.

Błaszczak, A. (26.03.2021). Regulatorzy podnoszą poprzeczkę i to nie tylko dla liderów biznesu. Rzeczpospolita, Dodatek specjalny Biznes Odpowiedzialny w Polsce, s. S2.

Chłapek, K., Krajewska, S., Jonas, K. (2019). Zrównoważony paradygmat kształcenia w szkole wyższej w kontekście sprawozdawczości zintegrowanej - z perspektywy nauczyciela akademickiego. Zeszyty Teoretyczne Rachunkowości, 103, 159, s. 23-28. DOI: 10.5604/01.3001.0013.3073.

Drumlak, U. (2011). Propozycja zastosowania niekonwencjonalnych metod nauczania rachunkowości w szkołach wyższych. Folia PomeranaeUniversitatisTechnologiaeSt etinensis:Oeconomica, 287, 63, s. 31-44.

Gaebel, M., Kupriyanova, V., Morais, R., Colucci, E. (2014). E-learning in European Higher Education Institutions: Results of a mapping survey conducted in October-December 2013. Download: https://eua.eu/downloads/publications/e-learning\%20 in\%20european\%20higher\%20education\%20institutions\%20results\%20of\%20a\%20 mapping\%20survey.pdf.

Gmińska, R. (2018). Czy rachunkowość jako przedmiot nauczania może być nudna? Prace Naukowe Wyższej Szkoły Bankowej w Gdańsku, 52, s. 237-247.

INFOR (23.11.2020). Księgowi, technologia i społeczeństwo 5.0. Pobrane z: https:// ksiegowosc.infor.pl/rachunkowosc/zasady-ogolne/4734706,Ksiegowi-technologia-ispoleczenstwo-50.html.

Klinowski, M. (2017). Metodyka prowadzenia zajęć z rachunkowości podatkowej na uczelniach ekonomicznych. Folia PomeranaeUniversitatisTechnologiaeStetinensis, Oeconomica, 335, 87, s. 113-122. DOI: 10.21005/oe.2017.87.2.11.

Kłobukowska, J. (2020). Raportowanie zintegrowane w procesie budowania wartości dla inwestorów na rynku kapitałowym. Pieniq̨dze i Więź, 88, 3, s. 47-55.

Król-Stępień, M. (2013). System informatyczny rachunkowości jako narzędzie wspomagające zarządzanie jednostką gospodarczą - wymogi ustawowe a ich praktyczne stosowanie. Zeszyty Naukowe Uniwersytetu Szczecińskiego Finanse, Rynki Finansowe, Ubezpieczenia, 757, 58, s. 75-81.

Sangster, A., Stoner, G., Flood, B. (2020). Insights into accounting education in a COVID-19 world. Accounting Education, 29, 5, s. 431-562. DOI: 10.1080/09639284.2020.1808487.

Soczewka-Piwowarczyk, B. (8.12.2020). W czasie pandemii czas na e-księgowość i e-biura rachunkowe. Pobrane z: https://www.rp.pl/Rachunkowosc/312089976-W-czasiepandemii-czas-na-e-ksiegowosc-i-e-biura-rachunkowe.html. 